ACADEMIA ROMÂNĂ
Rev. Roum. Chim.,
Revue Roumaine de Chimie
http://web.icf.ro/rrch/

\title{
SYNTHESIS, ANTIMICROBIAL ACTIVITY, UREASE INHIBITION AND MOLECULAR DOCKING STUDIES OF NEW PROLINE LINKED THIOUREA DERIVATIVES
}

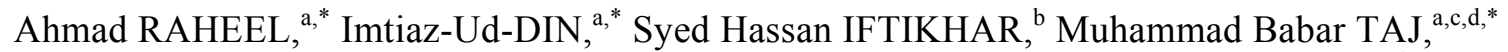 \\ Rabia AYUB, ${ }^{\mathrm{e}}$ Anham ZAFAR, ${ }^{\mathrm{a}}$ Sumaira ABBAS ${ }^{\mathrm{a}}$ and Mundher AL-SHAKBAN ${ }^{\mathrm{f}}$ \\ ${ }^{a}$ Department of Chemistry, Quaid-i-Azam University, Islamabad 45320, Pakistan \\ ${ }^{\mathrm{b}}$ Department of Chemistry, University of Engineering and Technology, Lahore 54890, Pakistan \\ ${ }^{\mathrm{c}}$ Department of Chemistry, Baghdad-ul-Jadid Campus, Islamia University of Bahawalpur, Bahawalpur 63100, Pakistan \\ ${ }^{\mathrm{d}}$ Department of chemistry, University of Sahiwal, Sahiwal 57000, Pakistan \\ ${ }^{\mathrm{e}}$ Department of Organic Chemistry, Arrhenius Laboratory, Stockholm University, SE-10691, Stockholm, Sweden \\ ${ }_{\mathrm{f}}$ Department of Chemistry, University of Manchester, M13 9PL, England
}

A series of new thiourea based carboxylic acids $\left(\mathbf{I}_{\mathbf{a}}-\mathbf{I}_{\mathbf{e}}\right)$ were synthesized and characterized by elemental analysis, FTIR and NMR $\left({ }^{1} \mathrm{H}\right.$ and $\left.{ }^{13} \mathrm{C}\right)$ spectroscopy. They were preliminary bioassayed for their antibacterial, anifungal and urease inhibition activities. Molecular docking simulations were carried out to determine the probable binding mode of the synthesized compounds. The bioassay results showed that some of titled compounds exhibited encouraging results.

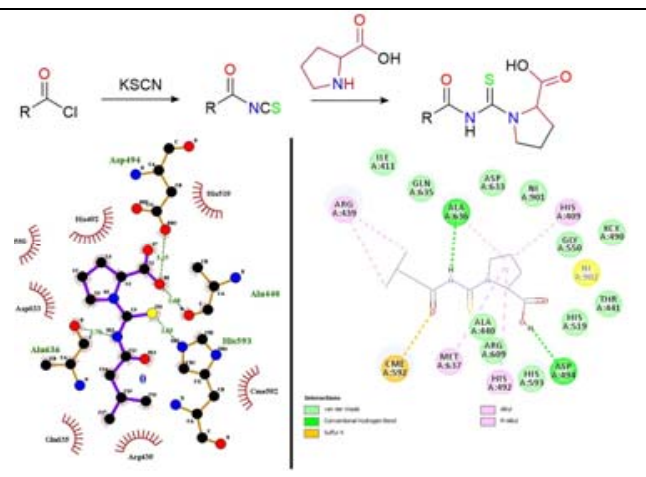

\section{INTRODUCTION}

Thiourea derivatives contain unique molecular structures with diverse pharmacological activities such as anti-inflammatory, ${ }^{1-2}$ antidiabetic, antioxidant, $^{3}$ antiulcer, ${ }^{4}$ antimycobacterials, ${ }^{5}$ antimicrobial ${ }^{3}$ and anticancer. ${ }^{6}$ The significance of thiourea derivatives is attributed to the nature of both thiocarbonyl $(\mathrm{C}=\mathrm{S})$ and carbonyl $(\mathrm{C}=\mathrm{O})$ groups in the molecular structure, ${ }^{1,7}$ which have an interesting influence on pharmacological behavior. Additionally, such interesting biological behaviors demonstrated by thiourea derivatives may also be attributed to their $\pi$ electron clouds as well as lone pairs present on oxygen, sulfur and nitrogen in their molecular configuration. ${ }^{1,8-9}$ Moreover thiourea derivatives can be also used as intermediates to construct other biologically active molecules with a thiourea backbone. $^{10}$ Thiourea derivatives act as selective analytical reagents particularly for the determination of a specific metal in the presence of many other metal ions. ${ }^{11-12}$ Thiourea derivatives serve as corrosion inhibitors, and with conjugated sulfur, oxygen or nitrogen donor sites, thiourea derivatives function as good chelating ligands. ${ }^{12}$ Metal complexes of these thiourea derivatives are utilized in supramolecular chemistry, homogenous catalysis, magnetic materials and chemical vapor deposition. ${ }^{11,13}$

*Correspondence: drimtiazuddin@yahoo.com, ahmadraheel001@gmail.com,drbabartaj@gmail.com 
Keeping in view the above aspects and in the continuation of our previous research work, ${ }^{14-15}$ we report herein the synthesis, structural characterization and biological activities of some substituted thiourea derivatives $\left(\mathbf{I}_{\mathbf{a}-} \mathbf{I}_{\mathbf{e}}\right)$.

\section{RESULTS AND DISCUSSION}

The compounds $\left(\mathbf{I}_{\mathbf{a}}-\mathbf{I}_{\mathbf{e}}\right)$ were synthesized by the reaction of respective acid chloride and potassium thiocyanate with the proline in stoichiometric amounts. They were fully characterized by FTIR and multinuclear NMR $\left({ }^{1} \mathrm{H}\right.$ and $\left.{ }^{13} \mathrm{C}\right)$ spectroscopies. The results of elemental analysis data are consistent with their proposed compositions. The spectroscopic data have been shown in the Experimental Section.

\section{FTIR spectra}

The pertinent IR absorption bands for $\left(\mathbf{I}_{\mathbf{a}}-\mathbf{I}_{\mathbf{e}}\right)$ have been identified by comparing the data with literature values. ${ }^{10,14}$ Bands in the range $3387-3467 \mathrm{~cm}^{-1}$ and $3227-3261 \mathrm{~cm}^{-1}$ are attributed to stretching frequencies of $\mathrm{OH}$ and $\mathrm{NH}$ groups. Bands, due to $\mathrm{C}=\mathrm{O}$ carboxylic stretching occurred in range 1712-1733 $\mathrm{cm}^{-1}$ and $\mathrm{C}=\mathrm{O}_{\text {amide }}$ in range $1667-1698 \mathrm{~cm}^{-1}$.

\section{NMR spectra}

The chemical shifts were identified by their multiplicity patterns, intensity and compared with reported values. From the integration curve, total number of protons were calculated, which match exactly with expected molecular structures of newly synthesized compounds $\left(\mathbf{I}_{\mathbf{a}}-\mathbf{I}_{\mathbf{e}}\right)$. The ${ }^{1} \mathrm{H}$ NMR spectra for $\left(\mathbf{I}_{\mathbf{a}}-\mathbf{I}_{\mathbf{e}}\right)$ show two distinct singlets in range 11.00-11.61 and 9.36-9.87 ppm which are attributed to carboxylic protons and amide protons respectively. Moreover, protons of pyrrolidine were found to resonates in the expected range $1.73-4.44$ ppm. $^{10}$

The ${ }^{13} \mathrm{C}$ NMR analysis further supports the structure of the target compounds $\left(\mathbf{I}_{\mathbf{a}}-\mathbf{I}_{\mathbf{e}}\right)$. All distinct carbon atoms present in the compounds were explicitly resolved by ${ }^{13} \mathrm{C}$ NMR. On the basis of alkyl signal intensities, alkyl carbon resonances are easily designated. By comparison of calculated chemical shifts from incremental method and experimental chemical shifts, the alkyl carbon resonances were designated ${ }^{1}$. As suggested from the previously published data, pyrrolidinic group shows signals in anticipated values (in range 26.8$59.8 \mathrm{ppm})^{10,16-17}$ Whereas carboxylic carbon resonates in range 173-178.9 ppm and $\mathrm{C}=\mathrm{S}$ resonate in range $180.6-188.5 \mathrm{ppm}$.

In accordance with the elemental analysis, FTIR and NMR spectral data, we suggest that the structures of $\left(\mathbf{I}_{\mathrm{a}}-\mathbf{I}_{\mathbf{e}}\right)$, resembles the general formula as suggested by Odame et al. ${ }^{10}$

\section{Biological Studies}

\subsection{Antimicrobial activity}

The synthesized compounds $\left(\mathbf{I}_{\mathbf{a}}-\mathbf{I}_{\mathbf{e}}\right)$ were preliminary bio-assayed against four fungal strains (A. Flavus, Trichoderma spp., A. Fumigatus, and A. Niger) and four bacterial strains (P. Aeruginosa, $S$. Aureus, E coli, and B. Subtlis) for their antifungal and antibacterial activity (data is given in Table 1). The synthesized compounds $\left(\mathbf{I}_{\mathbf{a}}-\mathbf{I}_{\mathbf{e}}\right)$ represented good to significant antibacterial activity (especially $\mathbf{I}_{\mathbf{a}}$ and $\mathbf{I}_{\mathbf{c}}$ ) and has the ability of inhibiting the growth of tested bacterial strains to various levels. This significant antibacterial activity of the $\left(\mathbf{I}_{\mathbf{a}}\right.$ and $\mathbf{I}_{\mathbf{c}}$ ) can be attributed to its antibacterial effects or from its bacteriostatic effects. In case of antifungal data, $\left(\mathbf{I}_{b}\right.$ and $\mathbf{I}_{\mathbf{d}}$ ) exhibited good performance in inhibiting the growth of fungal strains. Antifungal activities of $\left(\mathbf{I}_{b}\right.$ and $\left.\mathbf{I}_{d}\right)$ are comparable to the commercially available drug (Clotrimazole).

\subsection{Antiurease activity}

Antiurease properties of the compounds $\left(\mathbf{I}_{\mathbf{a}}-\mathbf{I}_{\mathbf{e}}\right)$ were screened by urease inhibitory assay (Table 2). The screening of the antiurease activities of the synthesized compounds $\left(\mathbf{I}_{\mathbf{a}}-\mathbf{I}_{\mathbf{e}}\right)$ revealed that compounds $\left(\mathbf{I}_{\mathbf{d}}\right.$ and $\left.\mathbf{I}_{\mathbf{e}}\right)$ inhibit more than $50 \%$ of urease inhibition activity. The compounds were further analyzed for the calculation of $\mathrm{IC}_{50}$ as compared to the standard drug thiourea. These were ascertained to be effective inhibitors of the urease and have shown significant activity comparable to the standard (thiourea). The potential inhibitory activity of the target compounds may be ascribed to their structural similarity to that of the thiourea (a natural substrate of urease). Subsequently, the bioactivity of the molecules cannot be decided by the impact of a lone variable or parameter. Moreover, in most of the cases, the existence of several groups in a molecule does not permit to exactly elucidate the potency and type of its bioactivity. ${ }^{18}$ 
Table 1

Antimicrobial data for $\left(\mathbf{I}_{\mathbf{a}}-\mathbf{I}_{\mathbf{e}}\right)$

\begin{tabular}{|c|c|c|c|c|c|c|c|c|}
\hline & $\begin{array}{l}S . \\
\text { Aureus } \\
\left(\mathbf{Z I}^{1}\right)\end{array}$ & $\begin{array}{l}\text { B. } \\
\text { subtlis } \\
\left(\mathbf{Z I}^{1}\right)\end{array}$ & $\begin{array}{l}\text { E. coli } \\
\text { (ZI) }\end{array}$ & $\begin{array}{l}\text { P. aeruginosa } \\
\left(\mathrm{ZI}^{1}\right)\end{array}$ & $\begin{array}{l}\text { A. } \\
\text { fumigatus } \\
\left(\mathrm{ZI}^{1}\right)\end{array}$ & $\begin{array}{l}\text { Trichoderma } \\
\text { spp. } \\
\left(\mathbf{Z I}^{1}\right)\end{array}$ & $\begin{array}{l}\text { A Niger } \\
\left(\mathrm{ZI}^{1}\right)\end{array}$ & $\begin{array}{l}\text { A Flavus } \\
\left(\mathbf{Z I}^{1}\right)\end{array}$ \\
\hline $\mathbf{I}_{\mathrm{a}}$ & 15 & 29 & 22 & 17 & 09 & 08 & 11 & 13 \\
\hline $\mathbf{I}_{b}$ & 08 & 09 & 13 & 07 & 13 & 14 & 18 & 15 \\
\hline $\mathbf{I}_{\mathbf{c}}$ & 19 & 06 & 22 & 15 & 10 & 13 & 19 & 16 \\
\hline $\mathbf{I}_{d}$ & 12 & 10 & 16 & 11 & 17 & 15 & 18 & 16 \\
\hline $\mathbf{I}_{e}$ & 12 & 20 & 18 & 14 & 18 & 12 & 09 & 10 \\
\hline SD* & 22 & 33 & 28 & 18 & & & & \\
\hline SD** & & & & & 24 & 17 & 21 & 19 \\
\hline
\end{tabular}

$\mathrm{ZI}^{1}$ : Zone of inhibition (in $\mathrm{mm}$ )

$\mathrm{SD}^{*}=$ Ciprofloxacin

SD $* *=$ Clotrimazole

Table 2

Urease inhibition data for $\left(\mathbf{I}_{\mathbf{a}}-\mathbf{I}_{\mathbf{e}}\right)$

\begin{tabular}{l|l|l|l}
\hline Sample Code & Concentration $(\mathrm{mM})$ & Inhibition $(\%)$ & $\mathrm{IC}_{50}(\mu \mathrm{mol})$. \\
\hline $\mathbf{I}_{\mathbf{a}}$ & 0.5 & 42.3 & - \\
$\mathbf{I}_{\mathbf{b}}$ & 0.5 & 78.3 & 49.8 \\
$\mathbf{I c}$ & 0.5 & 51.7 & - \\
$\mathbf{I}_{\mathbf{d}}$ & 0.5 & 89.4 & 29.8 \\
$\mathbf{I}_{\mathbf{e}}$ & & 81.1 & 33.19 \\
Thiourea & 0.5 & 97.60 & 23.64 \\
\hline
\end{tabular}

\section{Molecular docking analysis}

Molecular docking was implemented by following the previously published protocol ${ }^{19}$. The docking study was performed to clarify the binding mode of the synthesized compounds $\left(\mathbf{I}_{\mathbf{a}}-\mathbf{I}_{\mathbf{e}}\right)$ in the active site of jack bean urease (PDB code: 4H9M). For this purpose, $\left(I_{\mathbf{a}}-\mathbf{I}_{\mathbf{e}}\right)$ were docked onto the active site of the enzyme using Autodock Vina. The Autodock tool was used to anticipate the best fitted conformational orientation of the synthesized compounds against jack bean urease. The generated docked complexes were evaluated in accordance with minimum energy value $(\mathrm{kcal} / \mathrm{mol})$ as well as bonding interaction configuration (van der Waal, hydrogen, $\pi$-alkyl and alkyl). Docking results are in good agreement with our experimental findings. The minimum energy value $(-5.9 \mathrm{kcal} / \mathrm{mol})$ was found for $\left(\mathbf{I}_{\mathbf{d}}\right)$, which was comparatively higher than acetohydroxamic acid (-3.8 $\mathrm{kcal} / \mathrm{mol}$, during its re-docking), which is a well-known urease inhibitor.

Docking analysis showed that $\left(\mathbf{I}_{\mathbf{d}}\right)$ interacted with the active binding region of jack bean urease (as shown in Figures 2-3). The target compound was placed near the $\mathrm{Ni}^{+2}$ ions in the binding pocket of jack bean urease. In this position, $\left(\mathbf{I}_{\mathbf{d}}\right)$ interacted with ASP A:494 and ALA A:636 through hydrogen bond. The $\pi$-alkyl interactions were also observed between the $\left(\mathbf{I}_{\mathbf{d}}\right)$ and HIS (A:409 and A:492). The alkyl interactions were seen in the hydrophobic pocket containing side chain MET A:637 as well as ARG A:439. Two and three dimensional interaction patterns are shown in Figures 1-2. The relative SAR evaluation and the binding energy demonstrated that the essentialness of $\left(\mathbf{I}_{d}\right)$ may consider as powerful inhibitor by attacking jack bean urease.

\section{EXPERIMENTAL}

All chemical reagents were purchased from Merck (Germany) and were used as obtained from the supplier. Flash 2000 (elemental analyzer) was used to perform elemental analyses. Melting point was measured on the Gallenkamp (UK) instrument. Bio-Rad Excalibur FTIR Model FTS $3000 \mathrm{MX}$, was used to record Infrared spectra as $\mathrm{KBr}$ discs 4000-400 $\mathrm{cm}^{-1}$. On a Bruker 300 spectrophotometer working on 300 and $75.45 \mathrm{MHz}$ at ambient temperature, NMR spectra $\left({ }^{1} \mathrm{H}\right.$ and $\left.{ }^{13} \mathrm{C}\right)$ in solution were recorded. TMS was used as the internal reference.

\section{Synthesis}

\section{Thiourea Based Carboxylic Acids $\left(\mathbf{I}_{\mathbf{a}}-\mathbf{I}_{\mathbf{e}}\right)$}

The methodology used to synthesize the target compounds $\left(\mathbf{I}_{\mathbf{a}}-\mathbf{I}_{\mathbf{e}}\right)$ was the same as reported earlier ${ }^{14}$ with slight variation (Scheme 1). Solution of a substituted acid chloride $(5 \mathrm{mmol})$ in acetone $(20 \mathrm{~mL})$ was added dropwise to a suspension of $\operatorname{KSCN}(5 \mathrm{mmol})$ in acetone $(20 \mathrm{~mL})$. The reaction mixture was refluxed for an hour, resulting in the formation of intermediate isothiocyanate. A solution of proline $(5 \mathrm{mmol})$ in acetone $(20 \mathrm{~mL})$ was added and the resulting mixture was refluxed for additional 5 hours and afterwards the reaction mixture 
was poured into the ice containing beaker. The solid product obtained was filtered and recrystallized with methanol. The reaction scheme may be depicted as follows.

\section{Synthesis of 1-[(2,2-dimethylpropanamido)}

\section{methanethioyl]pyrrolidine-2-carboxylic acid $\left(\mathrm{I}_{2}\right)$}

Pivaloyl chloride (0.62 mL, $5 \mathrm{mmol})$, KSCN (0.49 g, $5 \mathrm{mmol})$, and proline $(0.58 \mathrm{~g}, 5 \mathrm{mmol})$ were used. Yield: $78 \%$. M.p.: $117{ }^{\circ} \mathrm{C}$. Anal. Calcd for $\mathrm{C}_{11} \mathrm{H}_{18} \mathrm{~N}_{2} \mathrm{O}_{3} \mathrm{~S}(258.34)$ : C, 51.14; $\mathrm{H}$, 7.02; N, 10.84; S, 12.41. Found: C, 51.11; H, 6.96; N, 10.80; S, $12.46 \%$. IR ( $\mathrm{KBr}$ pellets, $\left.v \mathrm{~cm}^{-1}\right): 3404(\mathrm{O}-\mathrm{H}), 3240(\mathrm{~N}-$ $\mathrm{H}), \quad 2969 \quad(\mathrm{C}-\mathrm{H} \quad$ alp $), \quad 1728 \quad(\mathrm{C}=\mathrm{O} \quad$ carboxylic $), 1689 \quad(\mathrm{C}=$ $\mathrm{O}$ amide), $1367(\mathrm{C}-\mathrm{N}), 772(\mathrm{C}=\mathrm{S}) .{ }^{1} \mathrm{H}$ NMR $\left(300 \mathrm{M} \mathrm{Hz}, \mathrm{CDCl}_{3}\right)$ : $\delta 11.00(1 \mathrm{H}, \mathrm{OH}), 9.74(1 \mathrm{H}, \mathrm{NH}), 4.44(1 \mathrm{H}, \mathrm{N}-\mathrm{CH}), 4.03(\mathrm{~m}, 2$ $\mathrm{H}), 2.18(\mathrm{~m}, 2 \mathrm{H}), 1.77(\mathrm{~m}, 2 \mathrm{H}), 1.27\left(9 \mathrm{H}, \mathrm{CH}_{3}\right) .{ }^{13} \mathrm{C} \mathrm{NMR}(75$
$\left.\mathrm{MHz}, \mathrm{CDCl}_{3}\right): \delta 180.6(\mathrm{C}=\mathrm{S}), 173.5(\mathrm{C}=\mathrm{OOH}), 172.1(\mathrm{C}=\mathrm{O}), 27.4-$ 58.4 ( $\left.\mathrm{C}_{\text {Pyrolidine }}\right)$.

\section{Synthesis of 1-I(2-methylpropanamido)}

methanethioyl]pyrrolidine-2-carboxylic acid $\left(\mathrm{I}_{\mathrm{b}}\right)$

Isobutyryl chloride $(0.52 \mathrm{~mL}, 5 \mathrm{mmol}), \mathrm{KSCN}(0.49 \mathrm{~g}$,

$5 \mathrm{mmol})$, and proline $(0.58 \mathrm{~g}, 5 \mathrm{mmol})$ were used. Yield: 67

\%. M.p.: $124{ }^{\circ} \mathrm{C}$. Anal. Calcd for $\mathrm{C}_{10} \mathrm{H}_{16} \mathrm{~N}_{2} \mathrm{O}_{3} \mathrm{~S}$ (244.31): C, 49.16; H, 6.60; N, 11.47; S, 13.12. Found: C, 49.12; H, 6.64; N, 11.46; S, 13.13\%. IR (KBr pellets, $\left.v \mathrm{~cm}^{-1}\right): 3387(\mathrm{O}-\mathrm{H})$, $3227(\mathrm{~N}-\mathrm{H}), 2983(\mathrm{C}-\mathrm{H}$ alp$), 1719(\mathrm{C}=\mathrm{O}$ carboxylic $), 1667(\mathrm{C}=$ $\left.\mathrm{O}_{\text {amide }}\right), 1362(\mathrm{C}-\mathrm{N}), 777(\mathrm{C}=\mathrm{S}) .{ }^{1} \mathrm{H}$ NMR $\left(300 \mathrm{M} \mathrm{Hz}, \mathrm{CDCl}_{3}\right)$ : $\delta 11.24(1 \mathrm{H}, \mathrm{OH}), 9.54(1 \mathrm{H}, \mathrm{NH}), 4.09(1 \mathrm{H}, \mathrm{N}-\mathrm{CH}), 4.01(\mathrm{~m}, 2$ $\mathrm{H}), 2.17(\mathrm{~m}, 2 \mathrm{H}), 1.73(\mathrm{~m}, 2 \mathrm{H}), 2.52(1 \mathrm{H}, \mathrm{CH}), 1.16\left(6 \mathrm{H}, \mathrm{CH}_{3}\right)$. ${ }^{13} \mathrm{C}$ NMR (75 MHz, $\left.\mathrm{CDCl}_{3}\right): \delta 181.3(\mathrm{C}=\mathrm{S}), 176.1(\mathrm{C}=\mathrm{OOH}), 174.4$ $(\mathrm{C}=\mathrm{O}), 28.1-59.3$ ( $\left.\mathrm{C}_{\text {Pyrolidine }}\right)$.

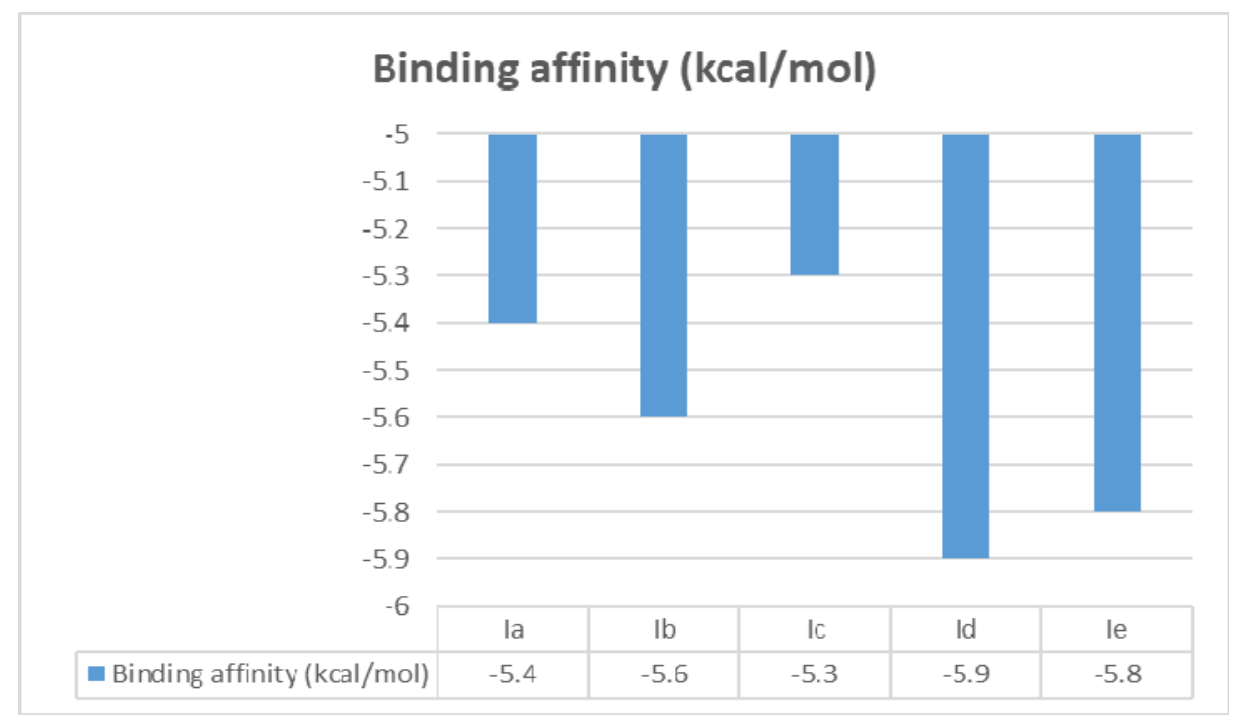

Fig. 1 - Binding energies $(\mathrm{kcal} / \mathrm{mol})$ of synthesized compounds with jack bean urease.
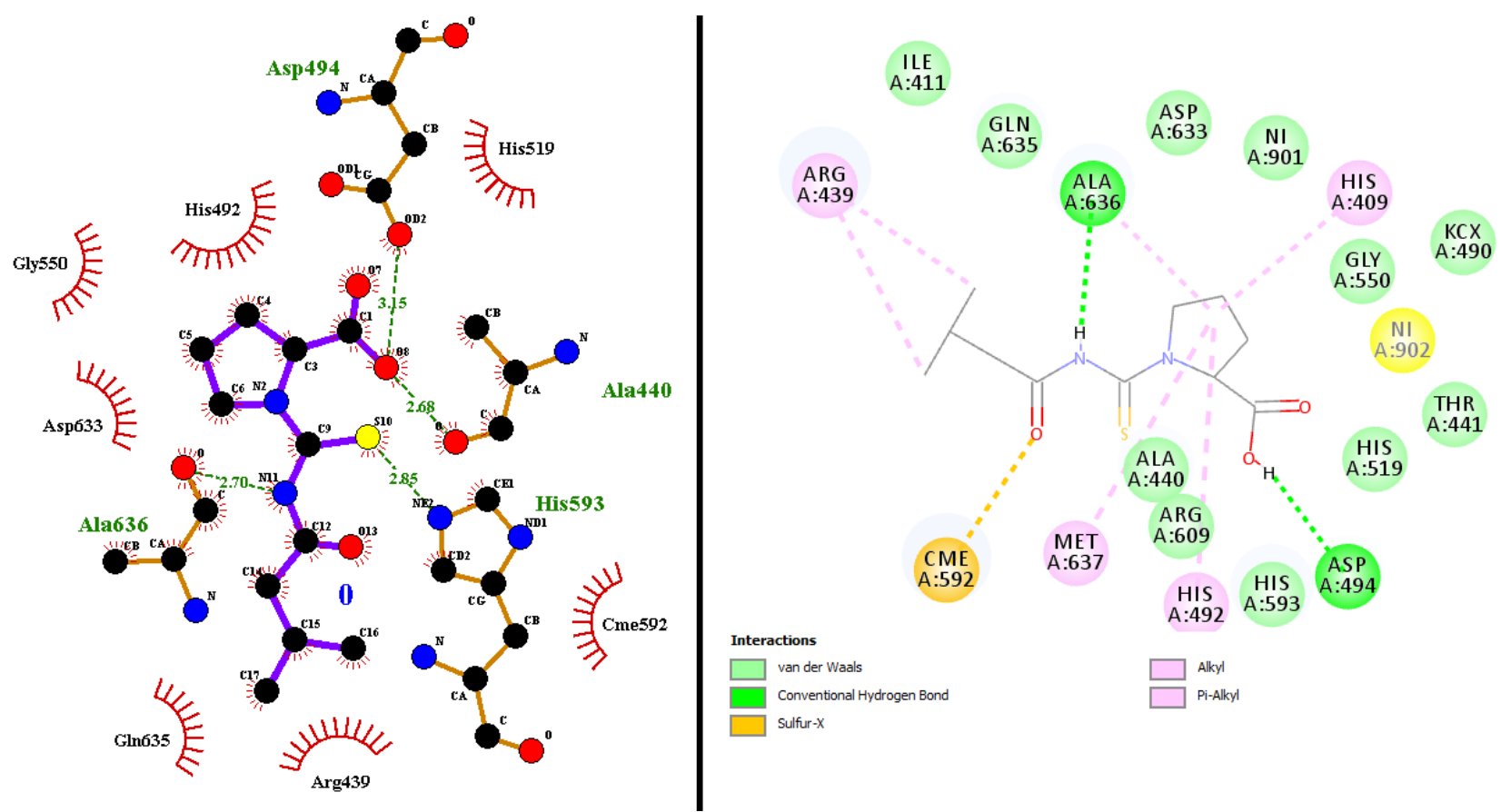

Fig. $2-2$ D representations of docking for $\left(\mathbf{I}_{\mathbf{d}}\right)$ in the active site of jack bean urease. 


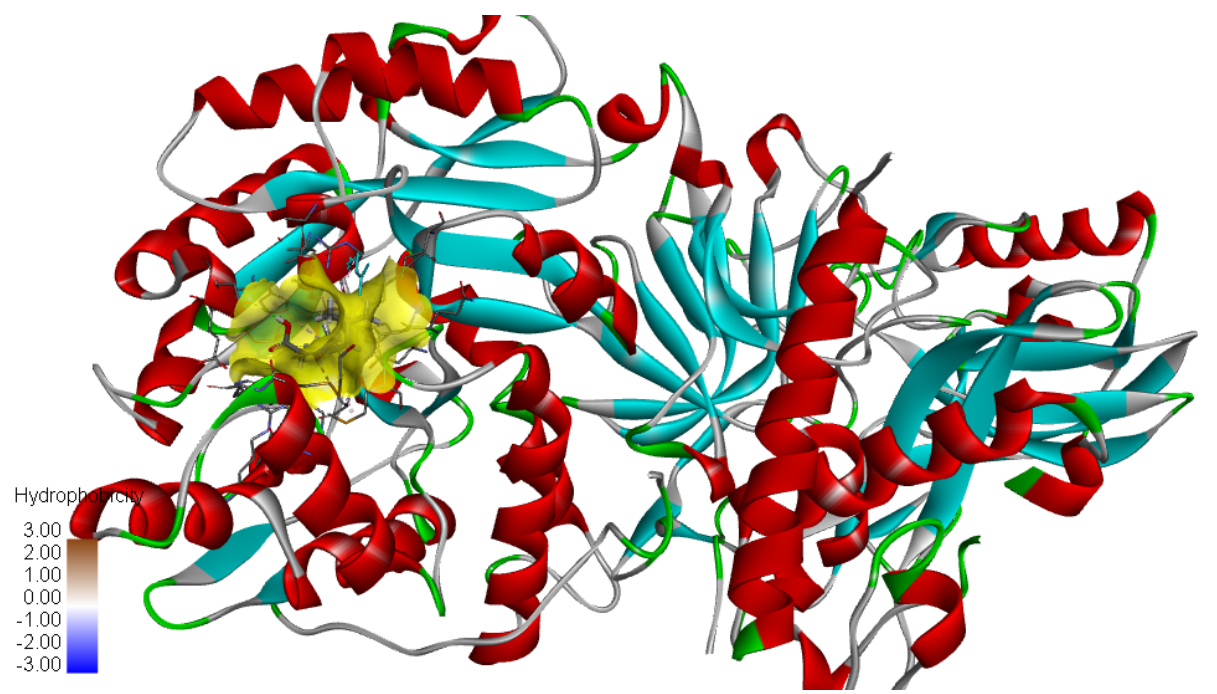

Fig. 3-3D representations of docking for $\left(\mathbf{I}_{\mathbf{d}}\right)$ in the active site of jack bean urease.

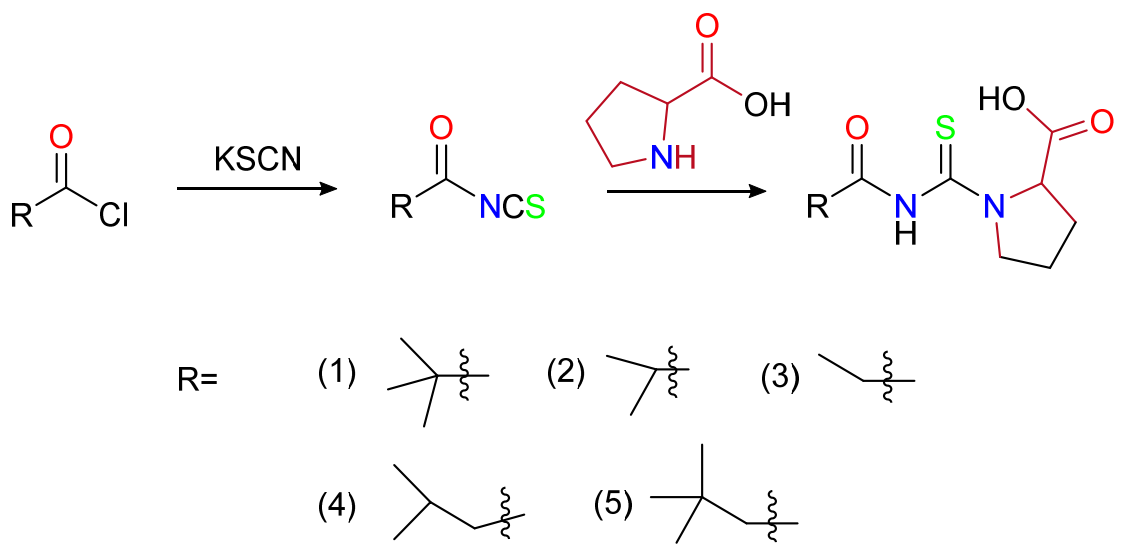

Scheme 1 - General scheme for the synthesis of compounds $\left(\mathbf{I}_{\mathbf{a}}-\mathbf{I}_{\mathbf{e}}\right)$.

Synthesis of 1-(propanamidomethanethioyl)pyrrolidine-2carboxylic acid $\left(\mathbf{I}_{\mathbf{c}}\right)$

Propionyl chloride $(0.44 \mathrm{~mL}, 5 \mathrm{mmol}), \mathrm{KSCN}(0.49 \mathrm{~g}$, $5 \mathrm{mmol})$, and proline $(0.58 \mathrm{~g}, 5 \mathrm{mmol})$ were used. Yield: 73 \%. M.p.: $134{ }^{\circ} \mathrm{C}$. Anal. Calcd for $\mathrm{C}_{9} \mathrm{H}_{14} \mathrm{~N}_{2} \mathrm{O}_{3} \mathrm{~S}$ (230.28): C, 46.94; H, 6.13; N, 12.17; S, 13.92. Found: C, 46.95; H, 6.18; $\mathrm{N}, 12.15 ; \mathrm{S}, 13.94 \%$. IR ( $\mathrm{KBr}$ pellets, $\left.v \mathrm{~cm}^{-1}\right): 3419(\mathrm{O}-\mathrm{H})$, $3239(\mathrm{~N}-\mathrm{H}), 2945(\mathrm{C}-\mathrm{H}$ alp $), 1712(\mathrm{C}=\mathrm{O}$ carboxylic $), 1673(\mathrm{C}=$ $\mathrm{O}_{\text {amide }}$ ), $1353(\mathrm{C}-\mathrm{N}), 784(\mathrm{C}=\mathrm{S}) .{ }^{1} \mathrm{H} \mathrm{NMR}\left(300 \mathrm{M} \mathrm{Hz}, \mathrm{CDCl}_{3}\right): \delta$ $11.28(1 \mathrm{H}, \mathrm{OH}), 9.87(1 \mathrm{H}, \mathrm{NH}), 4.24(1 \mathrm{H}, \mathrm{N}-\mathrm{CH}), 4.06(\mathrm{~m}, 2 \mathrm{H})$, $2.12(\mathrm{~m}, 2 \mathrm{H}), 1.76(\mathrm{~m}, 2 \mathrm{H}), 2.34\left(2 \mathrm{H}, \mathrm{CH}_{2}\right), 1.05\left(3 \mathrm{H}, \mathrm{CH}_{3}\right) .{ }^{13} \mathrm{C}$ NMR (75 MHz, $\left.\mathrm{CDCl}_{3}\right): \delta 188.5(\mathrm{C}=\mathrm{S}), 179.2(\mathrm{C}=\mathrm{OOH}), 175.6$ $(\mathrm{C}=\mathrm{O}), 26.8-59.2\left(\mathrm{C}_{\text {Pyrolidine}}\right)$.

\section{Synthesis of 1-[(3-methylbutanamido)}

methanethioyl]pyrrolidine-2-carboxylic acid $\left(\mathrm{I}_{\mathrm{d}}\right)$

3-methylbutanoyl chloride $(0.61 \mathrm{~mL}, 5 \mathrm{mmol}), \mathrm{KSCN}$ $(0.49 \mathrm{~g}, 5 \mathrm{mmol})$, and proline $(0.58 \mathrm{~g}, 5 \mathrm{mmol})$ were used. Yield: $69 \%$. M.p.: $142{ }^{\circ} \mathrm{C}$. Anal. Calcd for $\mathrm{C}_{11} \mathrm{H}_{18} \mathrm{~N}_{2} \mathrm{O}_{3} \mathrm{~S}$ (258.34): C, 51.14; H, 7.02; N, 10.84; S, 12.41. Found: C, 51.13; H, 6.97; N, 10.81; S, $12.43 \%$. IR ( $\mathrm{KBr}$ pellets, $\left.v \mathrm{~cm}^{-1}\right)$ : $3416(\mathrm{O}-\mathrm{H}), 3258(\mathrm{~N}-\mathrm{H}), 2961(\mathrm{C}-\mathrm{H}$ alp $), 1719(\mathrm{C}=\mathrm{O}$ carboxylic $)$, $1698\left(\mathrm{C}=\mathrm{O}\right.$ amide), $1376(\mathrm{C}-\mathrm{N}), 765(\mathrm{C}=\mathrm{S}) .{ }^{1} \mathrm{H}$ NMR $(300 \mathrm{M} \mathrm{Hz}$, $\left.\mathrm{CDCl}_{3}\right): \delta 11.61(1 \mathrm{H}, \mathrm{OH}), 9.63(1 \mathrm{H}, \mathrm{NH}), 4.18(1 \mathrm{H}, \mathrm{N}-\mathrm{CH}), 4.08$ $(\mathrm{m}, 2 \mathrm{H}), 2.17(\mathrm{~m}, 2 \mathrm{H}), 1.75(\mathrm{~m}, 2 \mathrm{H}), 2.15\left(2 \mathrm{H}, \mathrm{CH}_{2}\right), 2.04(1 \mathrm{H}$, $\mathrm{CH}), 0.99\left(6 \mathrm{H}, \mathrm{CH}_{3}\right) .{ }^{13} \mathrm{C} \mathrm{NMR}\left(75 \mathrm{MHz}, \mathrm{CDCl}_{3}\right): \delta 184.1(\mathrm{C}=\mathrm{S})$, 176.6 $(\mathrm{C}=\mathrm{OOH}), 172.7(\mathrm{C}=\mathrm{O}), 27.1-59.8\left(\mathrm{C}_{\text {Pyrolidine }}\right)$.

\section{Synthesis of 1-[(3,3-dimethylbutanamido)} methanethioyl]pyrrolidine-2-carboxylic acid $\left(\mathrm{I}_{\mathrm{e}}\right)$

3,3-dimethylbutanoyl chloride $(0.70 \mathrm{~mL}, 5 \mathrm{mmol}), \mathrm{KSCN}$ $(0.49 \mathrm{~g}, 5 \mathrm{mmol})$, and proline $(0.58 \mathrm{~g}, 5 \mathrm{mmol})$ were used. Yield: $65 \%$. M.p.: $156{ }^{\circ}$ C. Anal. Calcd for $\mathrm{C}_{12} \mathrm{H}_{20} \mathrm{~N}_{2} \mathrm{O}_{3} \mathrm{~S}$ (272.36): C, 52.92; H, 7.40; N, 10.29; S, 11.77. Found: C, 52.94; H, 7.37; N, 10.26; S, 11.75\%. IR ( $\mathrm{KBr}$ pellets, $v \mathrm{~cm}^{-1}$ ): $3467(\mathrm{O}-\mathrm{H}), 3261(\mathrm{~N}-\mathrm{H}), 2973(\mathrm{C}-\mathrm{H}$ alp $), 1733(\mathrm{C}=\mathrm{O}$ carboxylic $)$, $1671\left(\mathrm{C}=\mathrm{O}\right.$ amide), $1358(\mathrm{C}-\mathrm{N}), 775(\mathrm{C}=\mathrm{S}) .{ }^{1} \mathrm{H}$ NMR $(300 \mathrm{M} \mathrm{Hz}$, $\left.\mathrm{CDCl}_{3}\right): \delta 11.48(1 \mathrm{H}, \mathrm{OH}), 9.36(1 \mathrm{H}, \mathrm{NH}), 4.13(1 \mathrm{H}, \mathrm{N}-\mathrm{CH}), 4.04$ $(\mathrm{m}, 2 \mathrm{H}), 2.08(\mathrm{~m}, 2 \mathrm{H}), 1.78(\mathrm{~m}, 2 \mathrm{H}), 2.07\left(2 \mathrm{H}, \mathrm{CH}_{2}\right), 0.98(9 \mathrm{H}$, $\left.\mathrm{CH}_{3}\right) .{ }^{13} \mathrm{C} \mathrm{NMR}\left(75 \mathrm{MHz}, \mathrm{CDCl}_{3}\right): \delta 187.4(\mathrm{C}=\mathrm{S}), 178.9(\mathrm{C}=\mathrm{OOH})$, $174.1(\mathrm{C}=\mathrm{O}), 26.9-59.4\left(\mathrm{C}_{\text {Pyrolidine }}\right)$.

\section{Biological studies}

Agar tube dilution protocol ${ }^{20}$ and Agar well diffusion methods ${ }^{21}$ were used for the preliminary screening of the $\left(\mathbf{I}_{\mathbf{a}}\right.$ $\mathbf{I}_{\mathbf{e}}$ ) against different strains of fungi and bacteria. By following published protocols, the synthesized compounds were also tested for its antiurease $\mathrm{e}^{22-24}$ activity.

\section{Molecular docking study}

Autodock Vina (ver. 1.1.2) was used to study the molecular docking of the most active compound in in-vitro 
analysis, by using 3D crystal structure of Jack bean urease (PDB code: 4H9M), which is downloaded from the Protein Data Bank (www.pdb.org). All the hetroatoms were removed and the protein was then converted to pdbqt format using Autodock Tools (1.5.6). ${ }^{25}$ The 2D chemical structures of the synthesized compounds $\left(\mathbf{I}_{\mathbf{a}}-\mathbf{I}_{\mathbf{e}}\right)$ were sketched using Chem Draw Professional 13.0 and then energy minimized and converted to 3D format by Chem 3D 13.0. The Autodock Tool was then used to prepare the pdbqt format of the ligands. ${ }^{25}$ The docking analysis was performed using the following parameters: center $x=19.748$; center $y=-57.479$; center $z=-22.485$; size $x=15$; size $y=15$; size $z=15$. The docking results were established with DS visualizer Software, Version $4.0^{26}$ and ligplot. ${ }^{27}$

\section{CONCLUSIONS}

Thiourea based carboxylic acids $\left(\mathbf{I}_{\mathbf{a}} \mathbf{I}_{\mathbf{e}}\right)$ have been successfully synthesized and characterized by using spectroscopic analyses such as NMR $\left({ }^{1} \mathrm{H},{ }^{13} \mathrm{C}\right)$, FTIR, combined with elemental analysis. The synthesis of $\left(\mathbf{I}_{\mathbf{a}}-\mathbf{I}_{\mathbf{e}}\right)$ is repeated several times therefore synthetic method is authentic. Our results indicate that these compounds $\left(\mathbf{I}_{\mathbf{a}}-\mathbf{I}_{\mathbf{e}}\right)$ ensure favorable antibacterial and antifungal properties. The enzyme inhibition data exhibits that the target compounds

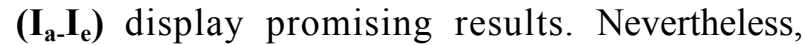
additional investigation is required to assess the compounds and also to understand its mode of mechanism of action comprehensively. However, these compounds might be considered for the drug designing programs in pharmaceutical domains.

Acknowledgements. The authors thank Q.A.U., Islamabad and The University of Manchester, England for the provision of the facilities to complete the research.

\section{REFERENCES}

1. W. M. Khairul, S. A. Suskri, R. Rahamathullah And N. Ismail, EJSMT, 2016, 3, 28-33.

2. W. Liu, J. Zhou, T. Zhang, H. Zhu, H. Qian, H. Zhang, W. Huang And R. Gust, Bioorg. Med. Chem. Lett., 2012, 22, 2701-2704.

3. H. Sudhamani, S. T. Basha, S. Adam, B. V. Bhaskar And C. N. Raju, Monatsh. Chem., 2017, 148, 1525-1537.
4. T. Yamada, Y. Nobuhara, H. Shimamura, Y. Tsukamoto, K. Yoshihara, A. Yamaguchi And M. Ohki, J. Med. Chem., 1983, 26, 373-381.

5. D. Sriram, P. Yogeeswari And K. Madhu, Bioorg. Med. Chem. Lett., 2006, 16, 876-878.

6. I. Koca, A. Özgür, K. A. Coşkun And Y. Tutar, Biorg. Med. Chem., 2013, 21, 3859-3865.

7. M. Emen, H. Arslan, N. Kulcu, U. Florke And N. Duran, Pol. J. Chem., 2005, 79, 1615-1626.

8. M. Lipowska, B. L. Hayes, L. Hansen, A. Taylor And L. G. Marzilli, Inorg. Chem., 1996, 35, 4227-4231.

9. D. S. Mansuroglu, H. Arslan, U. Flörke And N. Külcü, J. Coord. Chem., 2008, 61, 3134-3146.

10. F. Odame, E. C. Hosten, R. Betz, K. Lobb And Z. R. Tshentu, J. Mol. Struct., 2015, 1099, 38-48.

11. F. A. A. Ngah, E. I. Zakariah, N. I. Hassan, B. Yamin, S. Sapari And S. A. Hasbullah, Mal. J. Anal. Sci., 2017, 21, 1226-1234.

12. A. Singh, M. Bharty, P. Bharati, A. Bharti, S. Singh And N. Singh, Polyhedron, 2015, 85, 918-925.

13. F. A. Saad, Int. J. Electrochem. Sci, 2014, 9, 4761-4775.

14. A. Raheel, Imtiaz-ud-Din, A. Badshah, M. K. Rauf, M. N. Tahir, K. M. Khan, A. Hameed And S. Andleeb, J. Chem. Soc. Pak., 2016, 38, 1-6.

15. A. Raheel, Imtiaz-Ud-Din, S. Andleeb, S. Ramadan And M. N. Tahir, Appl. Organomet. Chem., 2017, 31 , E3632.

16. S. Tanimori, T. Naka And M. Kirihata, Synthetic Communications, 2004, 34, 4043-4048.

17. S. Poyraz, S. Belveren, M. Ülger, E. Şahin And H. A. Döndaş, Monatsh. Chem., 2017, 148, 2173-2182.

18. A. Saeed, S. Zaib, A. Pervez, A. Mumtaz, M. Shahid And J. Iqbal, Med. Chem. Res., 2013, 22, 3653-3662.

19. A. Raheel, M. Taj, M. Tahir And M. Al-Shakban, Russ. J. Gen. Chem., 2018, 88, 1508-1514.

20. Atta-Ur-Rahman, M. I. Choudhary And W. J. Thomsen, "Bioassay Techniques For Drug Development", Harwood Academic Publishers The Netherlands, 2001.

21. K. Allen, P. Molan And G. Reid, J. Pharm. Pharmacol., 1991, 43, 817-822.

22. G. Murtaza, A. Badshah, M. Said, H. Khan, A. Khan, S. Khan, S. Siddiq, M. I. Choudhary, J. Boudreau And F.-G. Fontaine, Dalton Trans., 2011, 40, 9202-9211.

23. M. W. Weatherburn, Anal. Chem., 1967, 39, 971-974.

24. A. Raheel, Imtiaz-Ud-Din, M. B. Taj, R. Ayub, M. N. Tahir, J. Raftery And M. Al-Shakban, Chemistry Select, 2019, 4, 8638-8644.

25. G. M. Morris, R. Huey, W. Lindstrom, M. F. Sanner, R. K. Belew, D. S. Goodsell And A. J. Olson, J. Comput. Chem., 2009, 30, 2785-2791.

26. D. S. Biovia And R. Dsme, San Diego: Dassault Systèmes. Release: 2015.

27. A. C. Wallace, R. A. Laskowski And J. M. Thornton, Protein Engineering, Design And Selection, 1995, 8, 127134. 